\title{
超音波断層法の歯周組織診査への応用
}

\author{
第二報＼cjkstart歯周外科処置後の歯周組織の変化について \\ 大 嶋 清 秀 \\ 東京医科歯科大学歯学部第二歯科保存学教室 \\ (主任, 指導 : 石川烈教授) \\ (平成 3 年 12 月 13 日受付)
}

\section{Application of Ultrasonography for the Diagnosis \\ of Periodontal Tissues \\ 2. Changes in Periodontal Tissues Following \\ Surgical Procedures}

Kiyohide OHSHIMA

Department of Periodontology, Faculty of Dentistry,

Tokyo Medical and Dental University

5-45, Yushima 1-chome Bunkyo-ku, Tokyo 113, Japan

(Chief and Director: Prof. Isao Ishikawa)

In the treatment of periodontal disease, it is important to accurately assess the degree of destruction of periodontal tissue. At the facial/ oral and lingual regions, it is difficult to measure the level of the alveolar bone crest from dental roentgenograms.

In a previous study using $20 \mathrm{MHzB}$-mode ultrasonic equipment, I found that a multiple reflected ultrasonic echo could become visible, when the periodontal probe was inserted into periodontal pockets. A new standardized B-mode ultrasonic method which has high reliability in diagnosis in these regions has been established.

In this study, changes in periodontal tissues following periodontal therapy were investigated using this equipment. At the facial sites of incisors, the flap surgery were performed on 14 sites in 10 patients with periodontal disease.

Ultrasonic diagnosis was performed at the first visit, 3 months after the first visit and then every month for 6 months postoperatively.

The results were as follows:

1) The distance between the tip of the pocket probe and the alveolar bone crest increased significantly $(p<0.01)$ from $0.84 \pm 0.88 \mathrm{~mm}$ (at the first visit) to $2.35 \pm 1.10 \mathrm{~mm}$ ( 6 months postoperatively).

2) The height of alveolar bone crest significantly decreased during initial preparation $(p<0.05)$, but various types of changes were observed after surgical procedures.

3) When the thickness of the alveolar bone was diminished at the first visit, the height of the alveolar crest decreased more rapidly after the initial preparation $(p<0.01)$.

4) The thickness of the alverolar bone had decreased significantly $(p<0.05) 1$ month post surgery.

Key words : Ultrasonography, Standardization, Alveolar bone crest, Periodontal disease, Periodontal 
therapy

要旨：歯周治療を行うに際して, 組織破壊の程度を的確に把握することは非常に重要であるが, 一般的に行われ ているX線写真では歯根に重なる唇頓側の歯槽骨辺縁の観察は困難である。

今回の実験では, 歯周疾患患者 10 名の前歯部 14 部位に対して, 歯周治療とくに歯周外科処置後の変化を超音波 診断装置を用いて調べた。診査は，初診時，歯肉剥離搔爬手術(初診からおよそ 3 力月), 手術後 6 力月まで 1 力月 おきに行った。

その結果，1）ポケット探針先端と歯槽骨頂間の距離は初診時 $(0.84 \pm 0.88 \mathrm{~mm})$ と比較して手術後 6 力月 $(2.35 \pm 1.10 \mathrm{~mm})$ では統計学的に有意に増加した。2）初期治療後に有意な歯槽骨頂の高さの減少が認められた が, 手術後の変化には多様性がみられた。3）初診時の歯槽骨の厚さが薄いほど, 初期治療中の歯槽骨頂の高さが有 意に減少した。4）手術後 1 力月で，有意な歯槽骨厚さの減少が認められた。

索引用語：超音波断層法，規格化，歯槽骨頂，歯周疾患，歯周治療

\section{緒 言}

歯周治療に際して, 診查時にその組織の破壊程度を 的確に把握することによってその予後を推測すること も可能である。従来, 歯槽骨の吸収の程度や形態の診 查には主にX線診查が行われてきた。しかし，X線写 真では歯間部歯槽骨や厚い頓舌側の歯槽骨辺縁は観察 できるが，歯根に重なる薄い歯槽骨辺縁は観察できな いことが多い ${ }^{1,2)}$ 。そこで，X線不透過性のシルバーポ イントやガッタパーチャポイントを歯周ポケットに挿 入して, X線撮影を行い歯周疾患の状態を確認したり, 浸潤麻酔下で，細いポケット探針を用いて歯肉外面を 穿通して骨欠損の状態を確認する方法も有用であると 報告されている3゙。しかし，これらの方法は日常的に行 うには組織を健全に保つ上で好ましいとは思えない。 近年，X線診査の種々の欠点を補うために，超音波 診断装置が用いられている ${ }^{4,5)}$ 。その中でもとりわけB モード法表示によるものを歯科領域に応用する試みが なされている。保存領域では歯根部歯周組織や根尖部 歯周組織を診査したものが ${ }^{6 \sim 9)}$, 補綴領域では義歯床下 粘膜の厚みを計測したものが報告されている ${ }^{10 \sim 12) 。 し ~}$ かし, 超音波診査では診査部位を厳密に確定できない という久点があり，それを解決するために著者はポ ケット探針を超音波診査におけるガイドとして用いる ことによってX線写真では診查困難な唇煩側に対して 診査部位を規定し歯周組織の変化を経時的に観察でき る可能性を第一報として報告した9)。歯周ポケットに ポケット探針を挿入した状態で超音波診査を行うとポ ケット探針の挿入された部位に，超音波映像上で多重 反射によるアーチファクトが生じ，これが診査部位を 確定するための基準点となることを見いだした。さら
に，この超音波画像によってポケット探針先端と歯槽 骨頂との間の距離，歯槽骨頂部の歯槽骨の厚さや歯肉 の厚さなどの変化を経時的に知ることができた。

すでに医学臨床の分野では臓器に対するドレナージ 時に超音波映像下で細い金属製穿刺針を確認しながら 確実に目的の臓器に誘導するなど金属に対するアーチ ファクトを利用することが行われている ${ }^{13)}$

そこで今回の実験は, この方法を臨床的に応用して 口腔内用超音波診断装置を用いてヒトの前歯部につい て初期治療や歯周外科処置に対する歯周組織, とくに 歯槽骨頂および歯槽骨厚さの変化と周囲軟組織の変化 を経時的に調べることを目的として行った。

\section{材料と方法}

\section{1）超音波診断装置について}

今回の実験に用いた超音波診断装置（図 1) は松下 技研株式会社（東京）で試作されたもので，口腔内用 超音波探触子, 通信回路, 受信回路, 画像記録回路, テレビモニター，付属回路，および画像を記録してお くためのテレビプリンターによって構成されている。 テレビモニター上には 2 画像まで表示可能で静止画像 上で, 生体内伝播時間に相当する距離目盛りによって 任意の 2 点間の距離を $0.1 \mathrm{~mm}$ 単位で測定可能であ る。

本機の口腔内用小型超音波探触子は図 2 に示すよう に, その先端部には周波数 $20 \mathrm{MHz}$ のチタン酸塩系セ ラミック振動子と超音波を集束させるための凹型音響 レンズが内蔵されており, 焦点距離はレンズから 10 $\mathrm{mm}$ のところに設定されている。そして, 駆動用モー ターにて毎秒 3 回のメカニカルセクター走査によって 画像を得る構造となっている。 


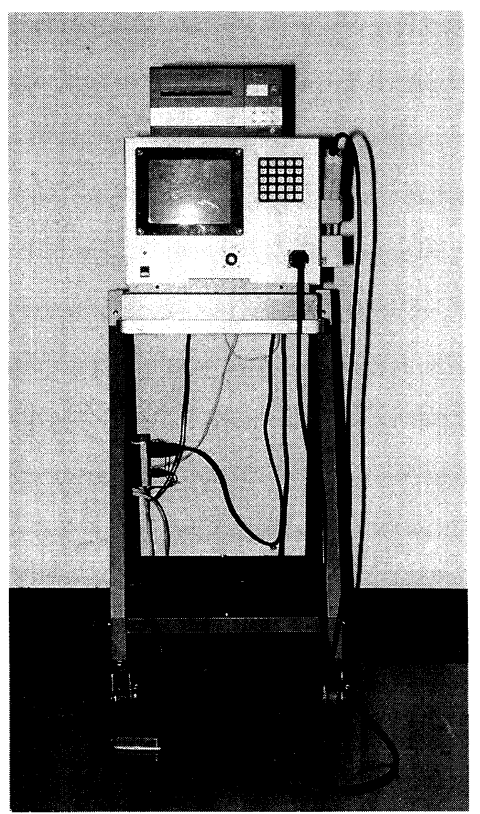

図 1 今回の実験に用いた歯科用超音波診断 装置の外観

\section{2）被験者}

本学歯学部付属病院に来院し, 成人性歯周炎と診断 された患者で通常の初期治療終了後, 上下顎前歯部唇 側に $4 \mathrm{~mm}$ 以上のプロービング深さを有し歯周外科処 置が必要と診断された患者 10 名 (男性 5 名, 女性 5 名) で，平均年齢は 46 歳であった。

被験部位は上顎 8 部位（中切歯 2 部位，側切歯 4 部 位, 犬歯 2 部位) 下顎 6 部位（中切歯 4 部位，側切歯 1 部位, 犬歯 1 部位) の計 14 部位を用いた。

被験歯には図 3 のようにレジンステントを作製しグ ルーブを形成して同一場所での診査を可能にした。

ポケット探針にはステント計測用探針 (15 mm 目盛 り, 直径 $0.6 \mathrm{~mm}$, (株) ワイデム・ヤマウラ製, 東京) を使用した。

\section{3）超音波診査}

ポケット探針を歯周ポケットに挿入した状態で超音 波診査を行うと，限定された 1 点において図 4 のよう なポケット探針の部分に超音波の多重反射によるアー チファクトを生じた超音波診断像があらわれる。この 画像上でポケット探針先端と歯槽骨頂間の距離, およ び歯根面と歯槽骨頂間および骨頂から $1 \mathrm{~mm}$ 根尖側に おいて歯根面との垂直距離をそれぞれ測定し，その平 均值を歯槽骨厚さとした。

さらに，臨床的付着位置とポケット探針先端と歯槽

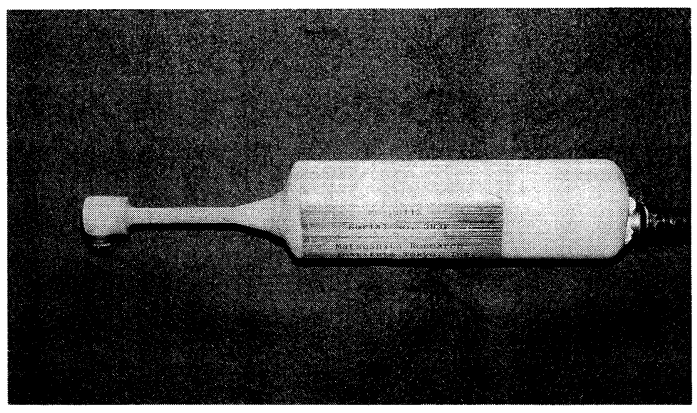

図 2 口腔内用小型超音波探触子

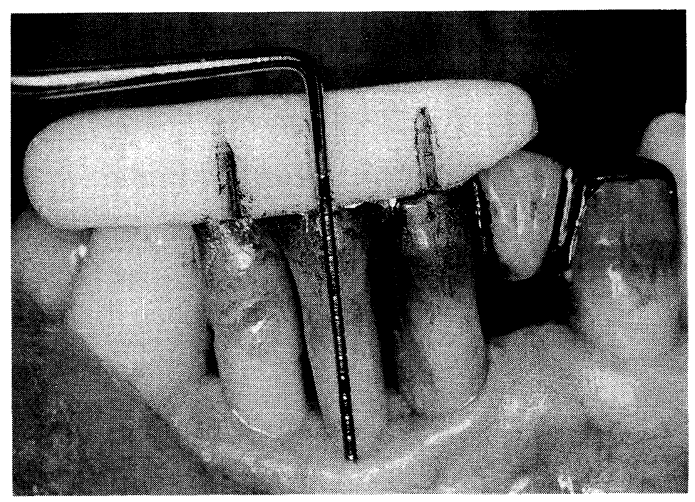

図 3 レジンステントを下顎前歯部に装着し ステント計測用探針を歯周ポケットに 挿入したところ

骨頂間の距離を加えることにより歯槽骨頂の位置を決 定した。なお，超音波診査は 1 部位につき 3 回ずつ行 いその平均值を測定值とした。

\section{4）一般臨床診查}

(1) 臨床的付着位置 (AL) 各被験歯ごとにレジンス テントを作製し， $1 \mathrm{~mm}$ 以下の測定にはノギスを用い て測定した。また，プロービング圧を $25 \sim 30 \mathrm{~g}$ に再現 できるようによく訓練したひとりの計測者によって 行った。

(2) 歯肉炎指数 (GI, Löe \& Silness 1963)

(3) プラーク指数（PII, Silness \& Löe 1964)

(4) プロービング深さ（PD）

について各被験者に対して行った。

\section{5）超音波診査，一般臨床診査の時期および治療方} 法

診查時期は初診時, 初期治療終了後歯肉剥離搔爬手 術直前（初診から約 3 力月）と術後 6 力月まで 1 力月 おきとした。 


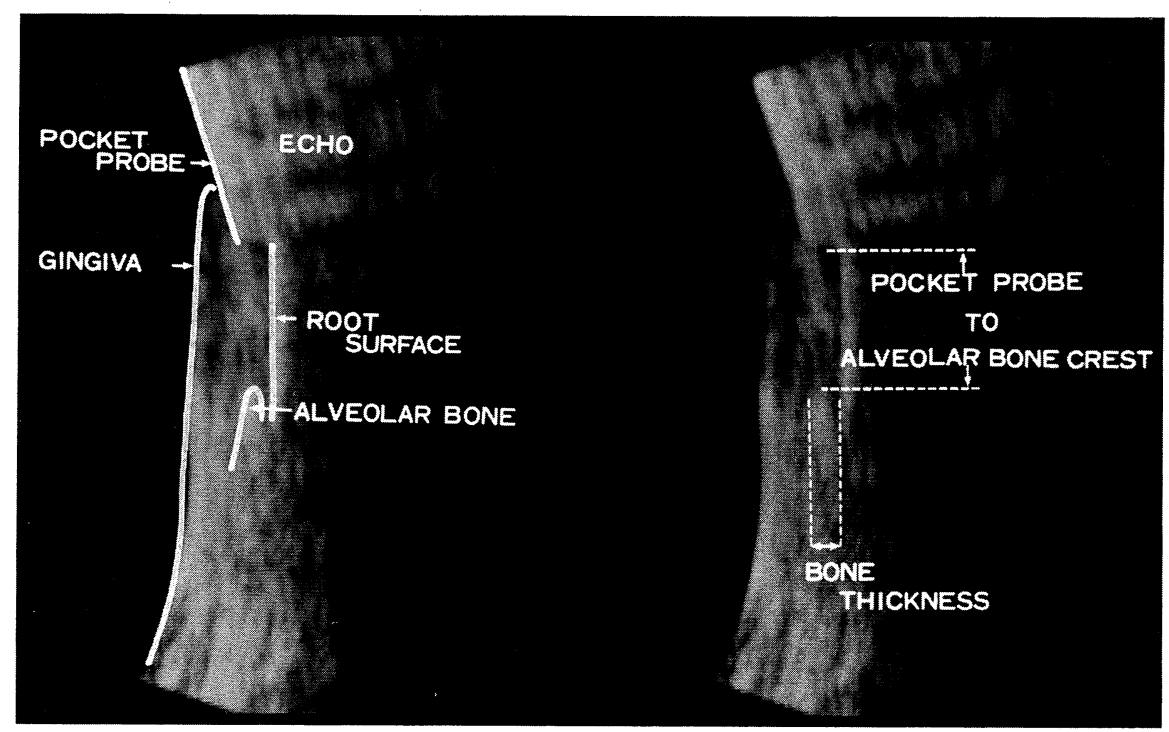

図 4 図 3 の状態で超音波診查を行うと上のような超音波断層像が得られる。左に 超音波断層像から得られる唇側歯周組織の解剖学的説明を示す。右に今回の 実験で測定した部位を示す。

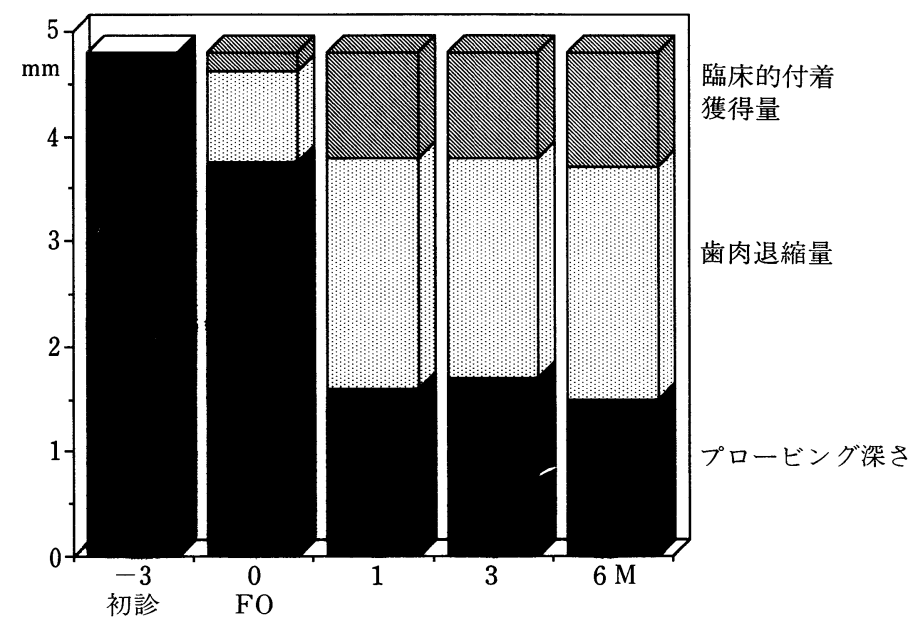

図 5 治療にともなう臨床的付着量, 歯肉退縮量, プロービン グ深さの変化

治療は通法どおり初期治療としてプラークコント ロール，スケーリング，ルートプレーニングを行い， 外傷性因子の認められた部位には速やかに咬合調整を 行った。初期治療終了後再評価を行い, 外科処置が必 要と診断された部位に対して歯肉剝離搔爬手術を行っ た。

手術法は, Full Thickness Flap とし，骨整形は一 切行わなかった。なお，被験部位の骨欠損形態はすべ て水平性骨吸収であることを術中に確認した。

\section{6）臨床例について}

今回の実験の中から最も特徵的な変化を示した症例 2 例について経時的な変化を臨床的指数と共に超音波 診断像およびその測定值をまとめた。

\section{結 果}

成人性歯周炎患者において現在行われている最も基 本的な治療方法に従い治療を進めた結果, 被験部位は 


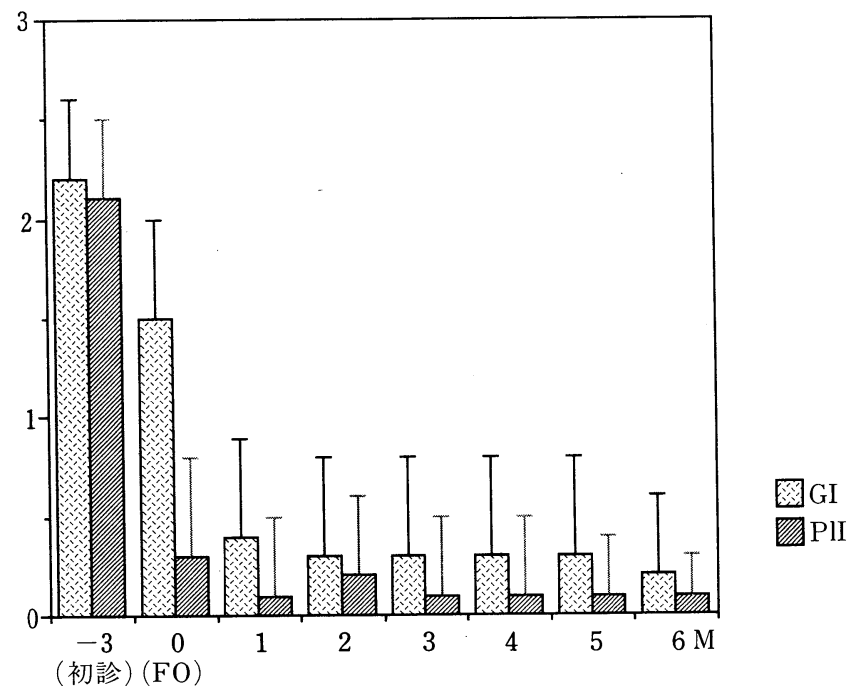

図 6 歯肉炎指数 $(\mathrm{GI})$ とプラーク指数（P $1 \mathrm{I} ）$ の変化

いずれも臨床的に改善がみられた。とりわけプロービ ング深さの改善が著しく（初診時平均 $4.8 \mathrm{~mm}$ が術後 6 力月では $1.5 \mathrm{~mm}$ ), 次いで初期治療や歯周外科によ る歯肉の退縮がめだった変化であった。(初期治療終了 までに $0.87 \mathrm{~mm}$, 手術後 6 力月で $2.20 \mathrm{~mm}$ ) また軟組 織に関して臨床的付着の獲得（手術後 6 力月で平均 $1.14 \mathrm{~mm}$ ) が認められた（図 5 )。

歯肉炎指数 (GI) とプラーク指数 (PII) はそれぞれ 初診時平均 2.2 と 2.1 であった。初期治療終了. 時 1.5 と 0.3 に手術後 6 力月で 0.2 と 0.1 にそれぞれ変化 し，口腔内は清潔に保たれ，歯肉の炎症もほとんど消 失した（図 6 )。

ポケット探針先端と歯槽骨頂間の距離の変化につい てみると, 初診時平均 $0.84 \pm 0.88 \mathrm{~mm}(\mathrm{MEAN} \pm \mathrm{SD})$ であったが, 初期治療終了時 $1.36 \pm 0.40 \mathrm{~mm}$ に, 手術 後 6 力月では $2.35 \pm 1.10 \mathrm{~mm}$ に変化したのが観察さ れ, paired t-test で統計学的に検定した結果, 初診時 および初期治療終了時と手術後とでは $p<0.01$ で統 計学的有意差が認められた(図 7 )。さらに，この変化 の意味を捉えるためにポケット探針先端と歯槽骨頂間 の距離と歯肉炎指数 $(\mathrm{GI})$ を $\chi 2$ 垂検定で統計処理し たところ歯肉の炎症が強いほどこの距離が短く, 逆に 炎症が少なくなるにつれてこの距離が長くなり $p<$ 0.01 で有意差が認められた(図 8 )。臨床的付着位置と ポケット探針と歯槽骨頂間の距離を加算して, 歯槽骨 頂の位置を定め, その経時的な変化を調べると, 初期 治療後に $0.39 \pm 0.42 \mathrm{~mm} （ \mathrm{MEAN} \pm \mathrm{SD})$ と歯槽骨頂

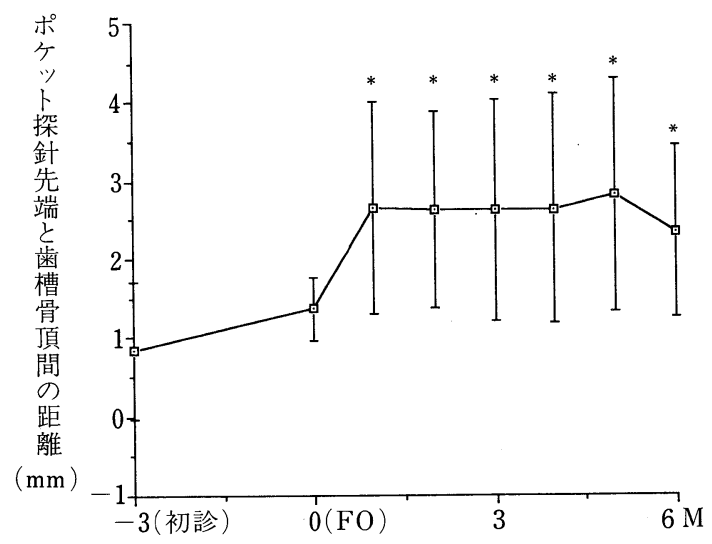

図 7 ポケット探針先端と歯槽骨頂間距離の経 時的変化

$$
\text { *と初診時で } p<0.01
$$

の高さの減少が認められた。手術時から術後 6 力月ま では $0.04 \pm 0.52 \mathrm{~mm}$ であり, 平均ではあまり変わらな いが歯槽骨頂の高さが増加するものや減少するものな ぞ様々の歯槽骨頂の高さの変化が認められた。その結 果, 初診時と初期治療終了後では $p<0.05$ で統計学的 有意差が認められた。しかし, 手術後の歯槽骨頂の高 さの変化に統計学的な有意差は認められなかった（図 9 )。

初診時における歯槽骨の厚さの平均は $0.74 \pm 0.36$ $\mathrm{mm}(0.40-1.44 \mathrm{~mm}$ ) で, 上顎 8 部位 (中切歯 1 部位, 側切歯 3 部位, 犬歯 4 部位) の平均が $0.73 \pm 0.28 \mathrm{~mm}$ (0.40-1.33 mm), 下顎 6 部位 (中切歯 4 部位, 側切歯 


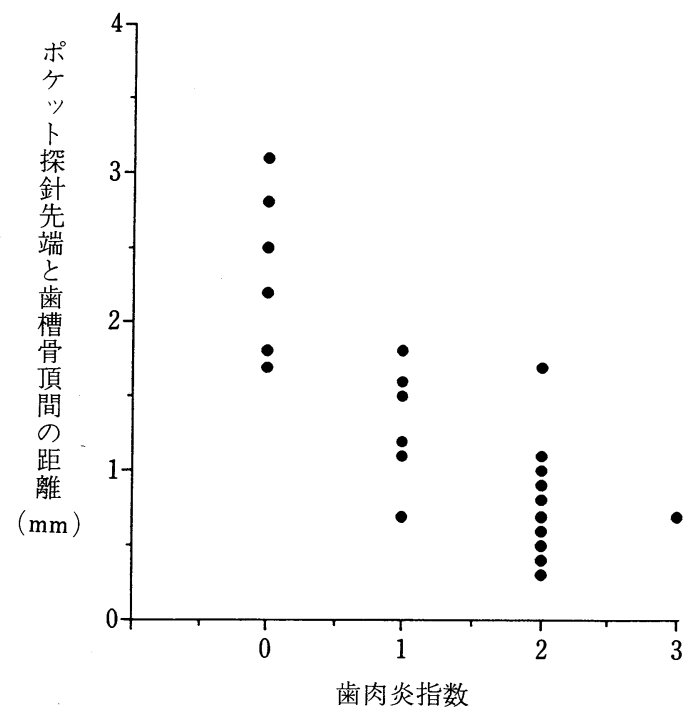

図 8 ポケット探針先端と歯槽骨頂間の距離と 歯肉炎指数とのカイ 2 乗検定 $p<0.01$ で有意差あり

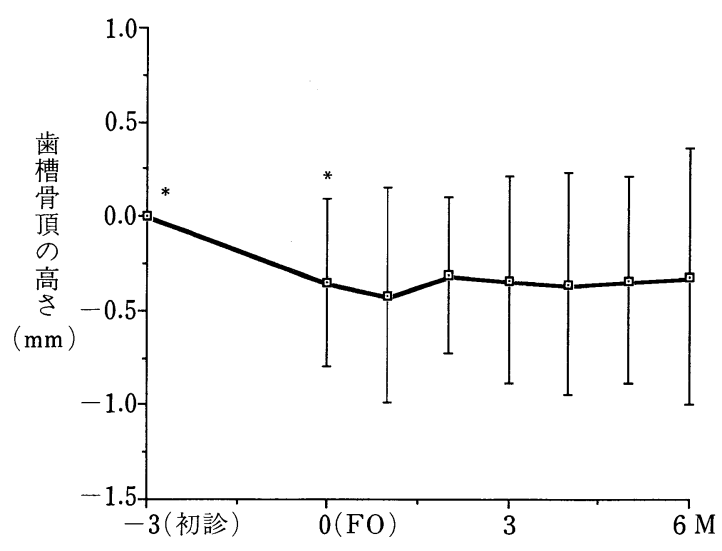

図 9 歯槽骨頂高さの経時的変化 **間で $p<0.05$

1 部位, 犬歯 1 部位)の平均が $0.75 \pm 0.44 \mathrm{~mm}$ と症例 数が少ないとはいえ上下顎で差は認められなかった。 手術後には上下顎ともに歯槽骨の厚さの減少が観察さ れたが減少量は上下䫟とも同様であった（表 1 )。

さらに初診時と手術後の歯槽骨の厚さの変化を paired t-test で検定した結果, 初診時の歯槽骨の厚さ と手術後 1 力月のそれとは $p<0.05$ で, 手術後 2 力月 以降では $p<0.01$ で統計学的有意差が認められ, 歯周 外科手術によって, 唇側歯槽骨の厚さが減少すること が示された（図 10）。

歯槽骨の厚さと歯槽骨頂の高さの変化量との相関を
表 1 初診時と手術後の歯槽骨の厚さの変化 上下顎間で歯槽骨厚さの変化に有意差なし（ t 検定）

\begin{tabular}{l|c|c}
\hline $\begin{array}{c}\text { 歯槽骨厚さ } \\
(\mathrm{mm})\end{array}$ & $\begin{array}{c}\text { 上顎 }(\mathrm{MEAN} \pm \mathrm{SD}) \\
\mathrm{n}=8\end{array}$ & $\begin{array}{c}\text { 下蕦 }(\mathrm{MEAN} \pm \mathrm{SD}) \\
\mathrm{n}=6\end{array}$ \\
\hline 初診時 & $0.73 \pm 0.28$ & $0.75 \pm 0.44$ \\
\hline 手術後 $6 \mathrm{M}$ & $0.58 \pm 0.27$ & $0.59 \pm 0.32$ \\
\hline
\end{tabular}

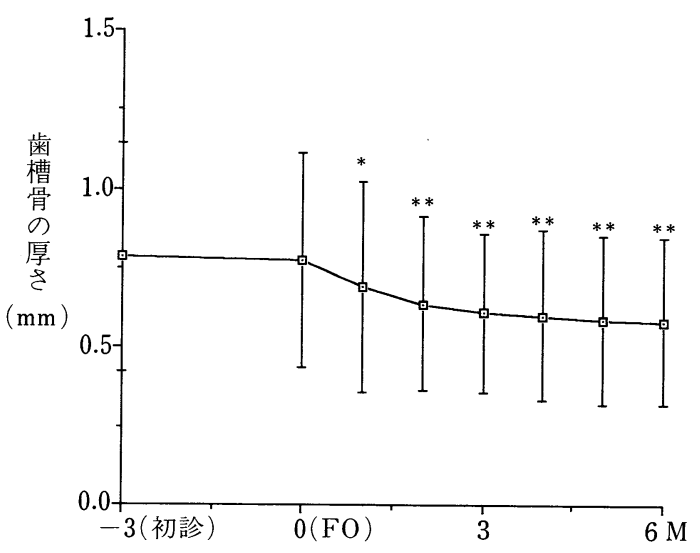

図 10 歯槽骨厚さの経時的変化（初診時との比較） $* p<0.05$ $* * p<0.01$

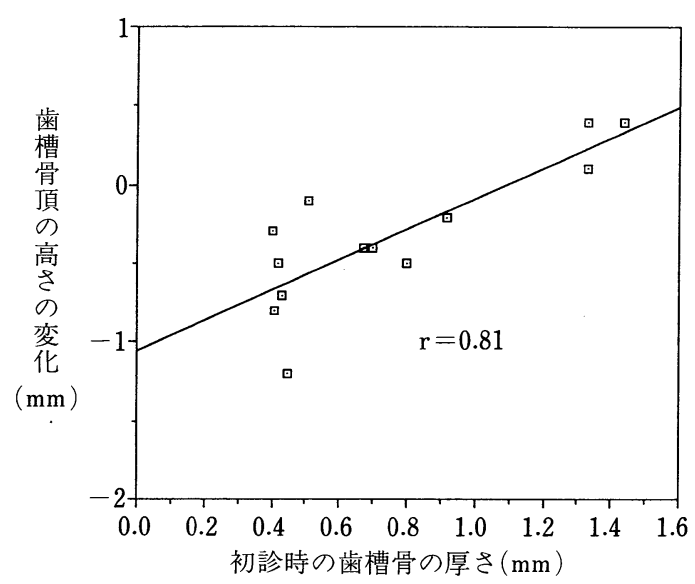

図 11 初期治療における歯槽骨頂の高さの変化 と初診時の歯槽骨の厚さとの相関

調べた結果，初期治療後における歯槽骨頂の高さは初 診時の歯槽骨の厚さが薄いほど, 歯槽骨の高さの減少 量が多く, 両者は相関係数 0.81 で正の相関が認められ た(図 11)。それに対して, 手術後の歯槽骨頂の高さの 変化量と初診時の歯槽骨の厚さとは有意な統計学的相 関は認められなかった。

ここで, 特徵的な歯槽骨の経時的変化を示した $2 つ$ 

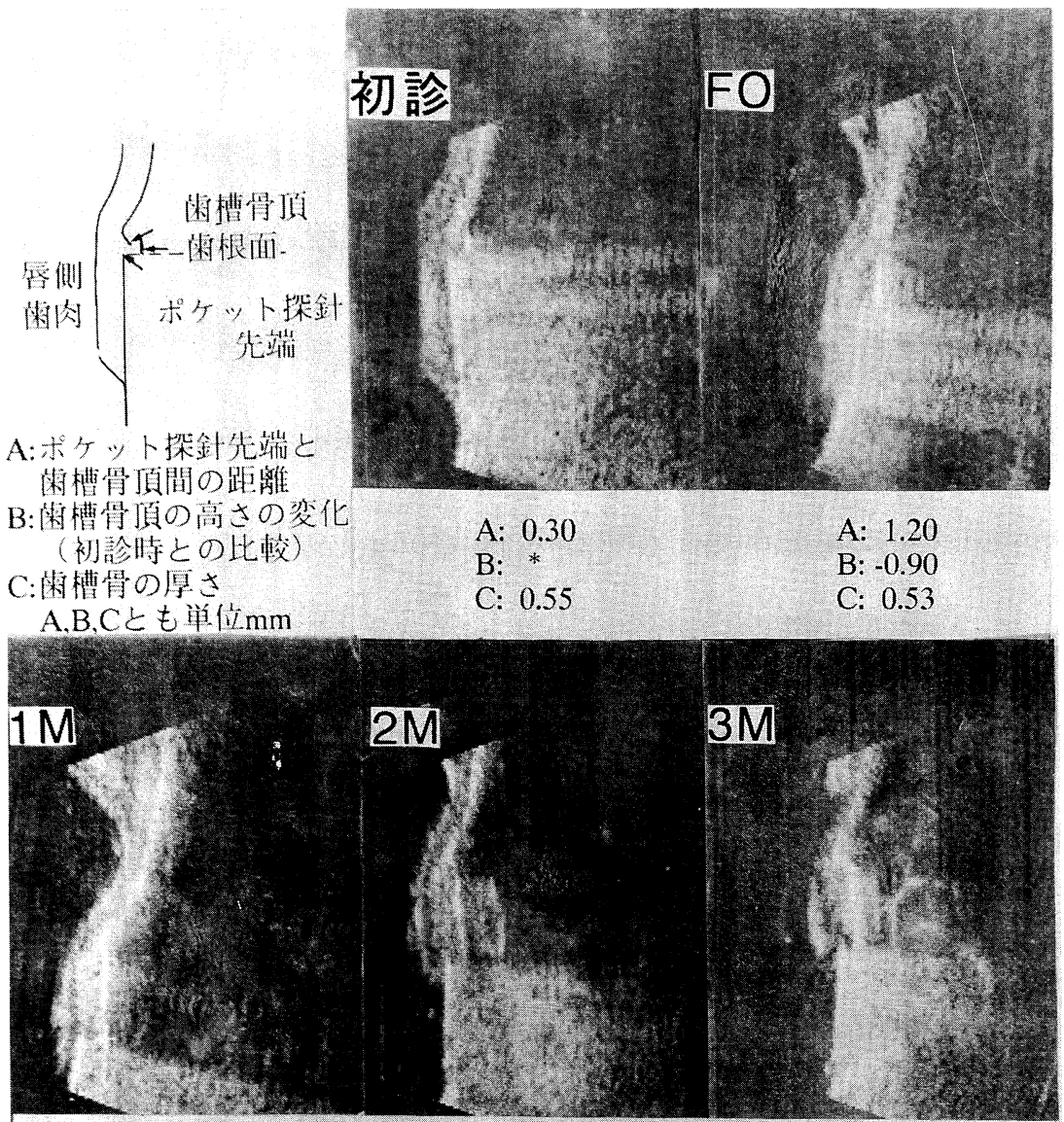
A: 2.00
A: 2.20
A: 2.20
B: -1.20
B: -1.40
B: -1.40
C: 0.52
C: 0.51
C: 0.51

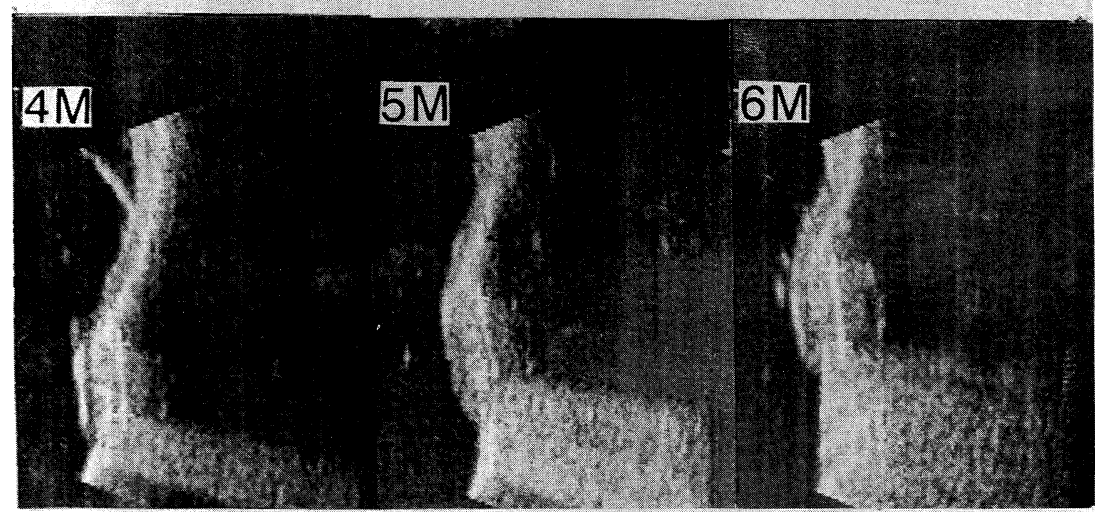
A: 2.00
A: 2.00
A: 2.00
B: -1.20
B: -1.20
B: -1.20
C: 0.53
C: 0.53
C: 0.53

図 12 被験者 $\mathrm{A}$ の経時的超音波断層像 


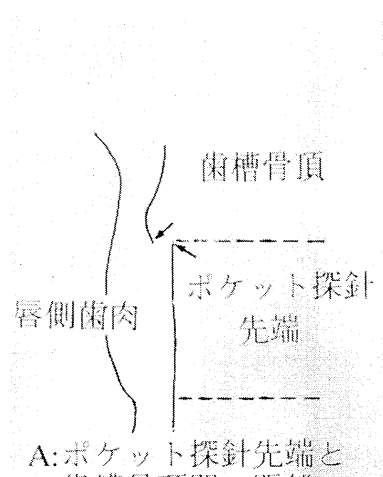

米槽骨顶間の距離

B:潾槽骨須の高さの变化 (初䊽時との比較) C:雨槽骨の厚さ

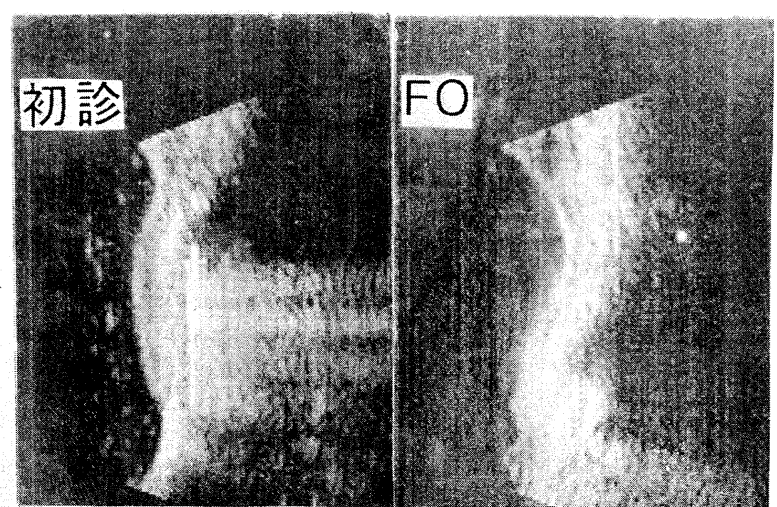

$$
\text { A,B,Cとも策位 } \mathrm{mm}
$$
A: 0.40
A: 1.70
B:
B: 0.40
C: 1.44
C: 1.24

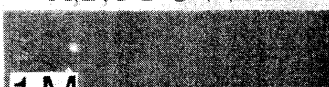

$1 \mathrm{M}$
A: 1.80
B: 0.60
A: 2.10
B: 0.30
C: 1.08
C: 0.97
A: 1.90
B: 0.50
C: 0.95

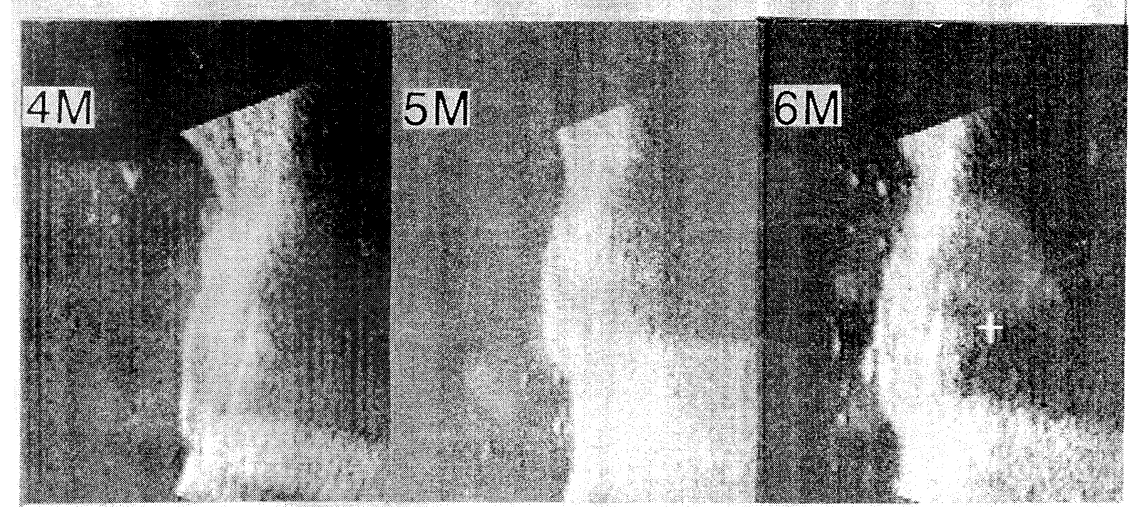
A: 1.90
A: 1.90
A: 1.90
B: 0.50
B: 0.50
B: 0.50
C: 0.91
C: 0.75
C: 0.74

図 14 被験者 Bの経時的超音波断層像 


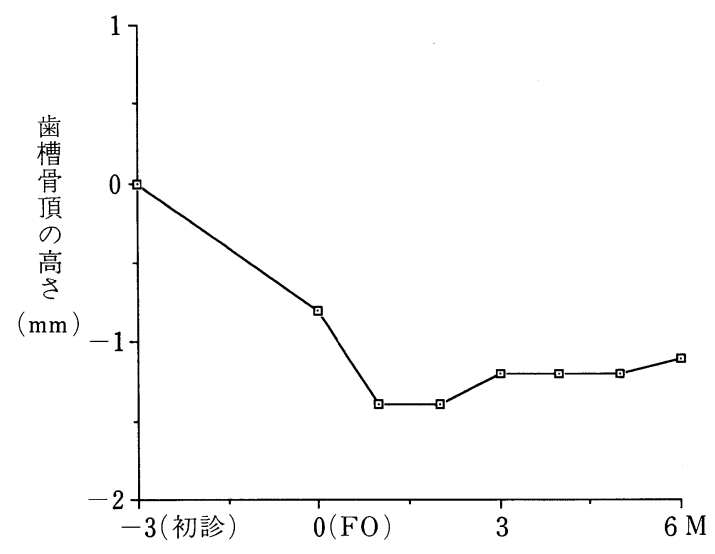

図 13 被験者 $\mathrm{A}$ の歯槽骨頂高さの経時変化

の症例を示す。

図 12 に示す経時的超音波断層像は, 初期治療および 術直後に歯槽骨頂の減少の認められた症例で, 被験者 は 42 歳の女性, 被験部位は下顎左側中切歯である。初 診時のプロービング深さは $5 \mathrm{~mm}$, プラーク指数, 歯肉 炎指数はともに 2 で, 初診時の歯槽骨の厚さは 0.55 $\mathrm{mm}$ であったが, 手術後でも $0.53 \mathrm{~mm}$ とほとんど変化 がみられなかった。また図 13 に示すように初診時と比 較して, 手術後 1 力月で $1.20 \mathrm{~mm}$ の歯槽骨頂の減少が 認められた。そして, 手術後 2 3 3 月にかけて 1.40 $\mathrm{mm}$ 減少し,その後は手術後 6 力月まで $1.20 \mathrm{~mm}$ の歯 槽骨頂の高さの減少が観察された。

図 14 に示す超音波断層像は初期治療中から歯槽骨 頂の高さの増加が認められた症例で, 被験者は 38 歳の 男性, 被験部位は同じく下顎左側中切歯である。初診 時のプロービング深さは $5 \mathrm{~mm}$, 歯肉炎指数, プラーク 指数はともに 2 , 初診時の歯槽骨の厚さは $1.44 \mathrm{~mm}$ で あった。経時的超音波断層像で, 初診時唇側歯槽骨の 形態が棚状であることが推測され，手術時にこのこと は確認できた。手術後 2 力月において歯槽骨頂付近の 骨の形態が変化していくのが観察され, 手術後 6 力月 で歯槽骨の厚さは $0.74 \mathrm{~mm}$ に減少したのが認められ た。また, 歯槽骨頂の高さは初診時から手術後 1 力月 まで $0.6 \mathrm{~mm}$ の高さの増加がみとめられ, 手術後 2 カ 月で $0.30 \mathrm{~mm}$ 減少し, 3 力月以降は $0.40 \mathrm{~mm}$ 増加した まま変化はみられなかった（図 15）。

\section{考 察}

$\mathrm{X}$ 線写真では歯間部歯槽骨や比較的厚い规舌側の歯

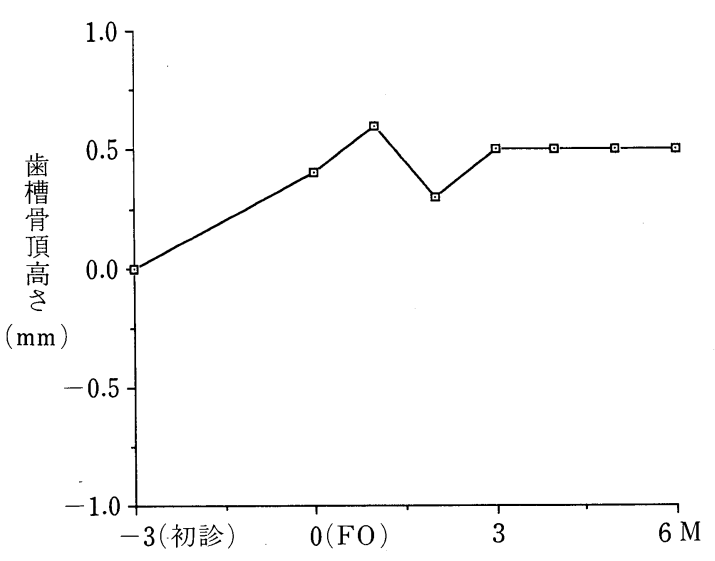

図 15 被験者 Bの歯槽骨頂高さの経時的変化

槽骨縁は観察できるが, 歯根に重なる薄い歯槽骨縁は, 煩舌側の間で吸収されるX線量全体に対して歯槽骨に 吸収されるX線量が非常に小さいため, 歯槽骨のある 部分とない部分の透過 $\mathrm{X}$ 線量の差が少なく, コントラ ストがつかないために観察できないことが多い1,2)。触 診や麻酔下で探針を用いて歯槽骨の外形を探ることが あるが3,14), このようにして得られた情報も確実なもの ではなく, 生体に加わる侵襲に関しても考慮しなけれ ばならない。超音波診断装置の利点はまさにこのX線 写真の欠点を補うものであり,さらに放射線の被爆と いうX線診査では避けて通れない問題も超音波診断で は為害性がなく安全性が確認されている10)。

超音波診断装置による計測值の信頼性に関して, 著 者は以前の報告9)でブタを用いて実験的にポケット探 針を歯肉溝内に固定しその測定值を実測值と比較した ところ誤差の割合は平均 $2 \%$ であったこと，および本 機と同じ超音波診断装置を用いた実験で分解能，すな わち近接する 2 カ所の反射波を分離して表示すること のできる能力に関して超音波の進行方向に存在する 2 点を識別する距離分解能は $0.15 \mathrm{~mm}$ ，それに直交する 2 点を識別する方位分解能は $0.27 \mathrm{~mm}$ であった ${ }^{10)} の$ で，本実験のように歯周治療後の歯周組織の経時的な 変化を観察するには十分な分解能を有していると思わ れた。

本実験においてポケット探針の位置を確認するため に用いた超音波映像上のエコーは多重反射と呼ばれ， これは超音波振動子から放射された超音波パルスが, 反射体すなわちポケット探針と振動子との間を何回も 往復して反射される現象で, 画像上で観察される帯状 のものはポケット探針目盛りの刻み目が映ったもので 
ある。これに関しても著者はほとんど 1 点でのみ起こ る現象であることを報告している9 。

本研究で測定したポケット探針先端と歯槽骨頂まで の距離の変化は歯肉の炎症の消退後に組織の緊密性が 増加したことと，歯周治療にともなう歯槽骨頂の高さ の変化の二つの因子によるものと考えられる。

すなわち, 現在までの多数の研究によって ${ }^{18 \sim 22)}$ ロービングに関する解釈は歯周組織に炎症が存在して いる状態では, 通常のプロービング圧 $(25 \sim 30 \mathrm{~g})$ でも ポケット探針の先端は上皮付着を穿通し結合組織に達 しており，逆に組織に炎症が無い状態では上皮付着の 最根尖側まですなわちポケット底までポケット探針の 先端は達していないことが知られている。このことか ら, プロービングの操作は単に歯周組織の緊密さの強 弱を調べていることになる。しかし, 日常の臨床にお いてプロービングによって得られる情報は非常に大き く, X線写真よりもプロービングにより得られるア タッチメントレベルの方が骨欠損の状態を正確に表し ているとの報告 ${ }^{33)}$ もる。それをふまえた上で, ポケッ 卜探針先端と歯槽骨頂の位置関係を客観的に距離表示 することは, 歯周組織の炎症の程度を表す一つの指標 となり得ると考えられる。

Ingber ら ${ }^{23)}$ は, 歯肉溝底部から歯槽骨頂までの距離 を Biologic Width という概念で提唱し, 臨床的には最 低 $2 \mathrm{~mm}$ 必要であると述べている。また, Gargiulo $ら^{24)}$ は歯周組織の加齢に伴う変化を組織学的に検索し て, 上皮性付着と結合織性付着を合わせて平均 2.04 $\mathrm{mm}$ であったと報告し, この距離は生体の恒常性に よって維持されていることを示唆した。しかし, 歯周 疾患や䠛蝕でこの Biological Width が維持できない 場合には歯周組織に対して損傷が起こると考えられて (る37)。

本実験の結果からもポケット探針先端と歯槽骨頂間 の距離が組織の炎症の程度を如実に表していると考え られ, 初診時の平均 $0.84 \mathrm{~mm}$ のときの歯肉炎指数の平 均が 2.2 であったこと, 初期治療終了時では平均 1.36 $\mathrm{mm}$ であり, そのときの歯肉炎指数が平均 1.5 であっ たこと, および外科処置 6 力月後では平均 $2.35 \mathrm{~mm}$ に，歯肉炎指数は平均 0.2 にそれぞれ変化したことか ら臨床的には $2 \mathrm{~mm}$ を基準として歯周組織の炎症の程 度を判断してもよいと思われる。しかし，ポケット探 針が歯石や歯の解剖学的な形態によって歯周ポケット に対して常に的確に挿入できないこともあるのでその 点には注意を払わなければならない。その点を除けば
超音波診断装置を用いることによって歯周組織の唇側 もしくは舌口蓋側に限定はされるがこの距離を為害作 用なしに簡便に調べられることは臨床的に有用と思わ れる。

歯肉剥離搔爬手術後の歯槽骨の変化に関しては, 過 去に多数報告されている。そのほとんどはX線を用い たものか, もしくは術後にリエントリー手術を行い実 測したものである。そのなかで本実験と同様に唇側お よび頓側の歯槽骨に関するものでは, Kohler ら ${ }^{25)}$ full thickness flap 後に平均 $0.23 \mathrm{~mm}$ の歯槽骨頂の吸 収が認められたと報告している。Donnenfeld ら ${ }^{26)}$ apically repositioned flap を抢こなって, 術後 4 力月 でリエントリー手術を行ったところ平均 $0.63 \mathrm{~mm}$ の 歯槽骨頂の吸収が認められたと報告している。 Tavtigian $^{27)}$ は apically repositioned flap を行い術後 4 カ月でリエントリー手術を行い計測したところ平均 $0.47 \mathrm{~mm}$ の唇側抢よび煩側の歯槽骨頂の吸収が認め られたと報告している。また, Wood ら ${ }^{28)}$ は full thickness flap と partial thickness flap を比較する実験で full thickness flap では平均 $0.62 \mathrm{~mm}$ の歯槽骨頂の吸 収が認められ，歯槽骨と結合組織の薄い部位で，歯槽 骨の吸収が大きいと述べている。以上の報告はフラッ プ手術時と手術数カ月後のリエントリー手術時との比 較であり, 本実験のごとく術後 1 カ月おきの経時的な 観察は為されていない。また，歯間部歯槽骨に関する 報告では, 川崎 ${ }^{29}$ は規格 X線写真を用いて歯間部歯槽 骨の手術後 10 力月の変化を観察し水平性吸収の部位 が最も骨の新生が少ないながら, 平均 $1.09 \mathrm{~mm}$ の骨の 高さの増加がみられたと報告している。また, 石原ら ${ }^{30)}$ は川崎の方法の規格X線写真により歯間部歯槽骨の面 積の経時的変化を観察し, 水平性吸収では手術後 3 力 月までは骨が減小し，それ以降は増加の傾向を示した としている。折笠 ${ }^{31}$ は基準化したX線写真で歯間部歯 槽骨の高さと面積の経時的変化を調べ, 石原ら ${ }^{30)}$ の結 果と同様に, 高さは手術後増加する傾向を示し, 面積 は 3 カ月後まで減少し, その後は増加する傾向を示し たと報告している。また, Dubrez ら ${ }^{38)}$ は歯間部歯槽骨 の変化を規格レントゲン写真の濃度変化で調べ, 手術 後 2 力月まで歯槽骨表層の濃度が減少し, その後手術 後 6 力月までその濃度は増加することを報告してい る。本実験の結果からは手術後 1 2 2 月で最も骨頂の 高さが減少したのが 9 症例, 術後 3〜 4 月で最も骨頂 の高さが減少したのが 2 症例, 術後 1 力月以降骨頂の 高さの増加が認められたのが 2 症例と. 症例間にばらつ 
きが認められた。さらに,すべての症例を平均すると 初期治療後に認められた歯槽骨頂の高さの減少の方が 外科手術 6 力月後までに観察されたそれよりも大き かった。この原因としては炎症の程度, 外科的侵襲, 歯槽骨厚さなどの解剖学的特徵, 骨欠損形態などが考 えられる。本実験の被験部位の骨欠損形態はすべて水 平性骨吸収であったことと, 炎症の程度に大きな差が 認められなかったことから，歯槽骨の薄い部位でのス ケーリング時には, 器具操作による外科的侵襲が骨頂 の減少を引き起こし易いことが示唆された。

今回の実験では外科手術後 6 力月までの観察とした のは組織の再生が最初の 6 力月以内に完結するとの報

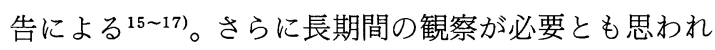
るが, プラークコントロールの良否によって歯槽骨の 変化が起こるであろうと推察できる。そして, 手術後 の歯槽骨頂の高さの経時的変化は増加した症例, 減少 した症例とほとんど変化しなかった症例の 3 パターン に分かれたことの原因として 1）歯槽骨の形態 2）超 音波診查の一断面性 3）手術時の歯槽骨頂上線維の除 去の程度の差, 外科手術部の歯肉弁の歯根および歯槽 骨面への密着度の差, 骨の露出されていた手術時間の 差などが考えられる。2)に関して，今回の実験では歯 の長軸に沿って超音波診査したため, 観察された歯槽 骨頂の変化が唇側歯槽骨全体の変化を示しているか, その診査部位だけにみられたものかは不明である。今 後は, 1 歯に扔ける超音波診査の走査の本数を増やす ことによってこのことは解決されると思われる。3）に 関して, 歯周治療が組織の炎症を除去することを目的 にしているにもかかわらず，その反面では人為的な侵 襲が組織に加わるという側面を考慮し, 健全な歯槽骨 頂上線維を可及的に残存させるべく努力し, 手術の基 本的な原則を守らなければならない。

本実験では歯槽骨の厚みを骨頂部における歯根面か らの垂直距離と歯槽骨頂から $1 \mathrm{~mm}$ 根尖側における歯 根面との垂直距離との平均值で表したが, この值が唇 側歯槽骨の厚さをどの程度的確に表わしているのかは 今後さらに検討が必要である。しかし, そのとき得ら れる超音波画像によって歯槽骨の厚さを数值ではなく 形態としてある程度推測できると考えられる。またこ の数値には歯根膜の厚さも含まれる。 $20 \mathrm{MHz}$ の超音 波は $1 \mathrm{~mm}$ の厚さの骨組織を透過することが報告され ており，歯槽骨の厚さだけでなく，歯根膜の厚さ（歯 根膜腔）を調べられる可能性が示唆されている ${ }^{34 ~ 36) 。 ~}$

歯槽骨の厚さの変化に関して, 手術後 1 力月から初
診時と比較して有意に減少し, 統計学的危険率は術後 1 力月で $5 \%$ 未満, 2 力月以降は $1 \%$ 未満であったこと から手術後 1 2 2 月にかけて歯槽骨のリモデリング が活発に行っていることが推測できる。加えて, 初診 時には歯槽骨頂部に扔いて不規則な骨吸収形態が観察 されたが炎症の消退にともなって, 除々に平坦な形態 に変化し, 結果的には歯槽骨の厚さが隇少したのは組 織の治瘺過程にともなうものと思われる。

これに関して小林 ${ }^{32}$ はサルを用いた実験的骨欠損部 の治癒を組織学的に観察し，歯間部歯槽骨に形成した 水平性骨欠損部では術後 1 2 週では破骨細胞の出現 と骨吸収がみとめられ, 術後 3 週以降では骨芽細胞の 数が増加し骨の新生がみとめられたと報告しており本 実験の結果からもこのことが裏付けられていると思わ れる。

一般的に外科処置による歯槽骨の露出によって骨表 面の吸収がおこることはよく知られている。海綿骨で 裏打ちされた皮質骨と皮質骨を補強する海綿骨がない 場合とでは皮質骨の吸収量に差が認められるとされて いる ${ }^{39}$ が，今回の結果からは歯槽骨の薄い部位におい て顕著な吸収は認められなかった。しかし, 外科処置 前に, 超音波診断装置によりこの情報を簡便に得るこ とによって, 処置法を決定し, 予後を推測することも 可能といえよう。

今後は部位特異性に関しても考慮して症例数を増や し様々な様相を示す術後の変化を更に細部にわたって 追求する必要性が認められた。

\section{結＼cjkstart論}

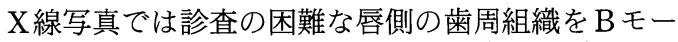
ド法表示による超音波診断装置を用いて歯周治療, と くに歯周外科手術後の変化を診查部位を規格化し, 経 時的に調べた。診查部位の規格化するために, 通常の 歯周治療で使用される金属製のポケット探針と診查対 象の歯ごとに作製したレジンステントを用い，超音波 画像上で出現するポケット探針に対する超音波の多重 反射によるアーチファクトを利用した。その結果，以 下の結論を得た。

1） ポケット探針先端と歯槽骨頂間の距離は，初診 時平均 $0.84 \pm 0.88 \mathrm{~mm}(\mathrm{MEAN} \pm \mathrm{SD})$ が, 手術後 6 力 月では $2.35 \pm 1.10 \mathrm{~mm}$ と有意に増加し, 歯肉炎指数 (GI) との関連からこの距離が歯周組織の炎症の程度 を表す指標となりえることが示唆された。 
2）歯槽骨頂の高さは初期治療中に統計学的に有意 に減少したが手術後の変化には症例間でばらつきがみ られた。

3）初期治療における歯槽骨頂の高さは初診時の歯 槽骨の厚さが薄いほど減少量が多く, 統計学的な相関 が認められた。

4) 初診時の歯槽骨の厚さは手術後 1 力月以降に有 意に減少し, 歯周外科手術が行われ治瘺が得られると, 唇側歯槽骨の厚さが減少することが示された。

\section{謝 辞}

稿を終えるにあたり, 終始御懇篤な御指導と御校閲を 賜った石川烈教授に謹んで感謝の意を表します。さらに,実 験に際し, 懇切丁寧に御指導御協力いただきました小田茂 講師をはじめ, 第 2 歯科保存学教室員各位に深く感謝の意 を表します。

\section{文献}

1) Goldman, H.M. and Stallard, R.E. : Limitations of the rediograph in the diagnosis of osseous defect in periodontal disease. J. Periodontol., $44: 626-628$, 1973.

2）井田瑞江，佐々木武仁，萩原さつき，石川 烈：歯 周疾患におけるデンタルX線写真の読影 その有用 性と限界, the Quintessence. 10：471-481, 1991.

3) Tibbetts, L.S. : Use of diagnostic probes for detection of periodontal disease. J. Am. Dent. Assoc., $78: 549-555,1969$.

4）村岡宣明，末田 武，木下四郎：超音波装置による 歯周組織診査一一歯肉, 歯槽粘膜, 歯槽骨の厚さに ついて—，日歯周誌，24:601-606, 1982.

5）村岡宣明：超音波装置による歯周組織診査——特に 歯槽骨辺縁形態について—，日歯周誌，24:40-53， 1982.

6）沢田健次，藤正敬夫，砂田今男：超音波断層法によ る歯周組織の映像について. 日歯周誌, 26(1) : 88-93, 1984.

7）沢田健次，砂田今男：超音波断層像による歯科診 断. 日本歯科評論, $516: 14-19,1985$.

8）沢田健次，藤正敬夫，砂田今男，福喜多博，屋野 勉, 福本 晃: 超音波映像技術の歯科応用につい て. 日超医講演文集, Oct：725, 1984.

9）大嶋清秀：超音波断層像の歯周組織診査への応用第 一報 診查方法の規格化について．日歯周誌，31： 235-240, 1989.

10）小林賢一，鈴木哲也，木村益巳，田中慎二，内田博 之, 長尾正憲：補経領域における超音波パルス反射 法の応用. 日補綴誌, 30:684-690, 1986.

11）内田博之, 小林賢一, 長尾正憲, 大規茂雄, 屋野
勉, 福喜多博：超音波による義歯床支持粘膜の診断 一その基礎的研究一. 日超医講演文集, July：585586, 1987.

12) H. Uchida, K. Kobayashi, and M. Nagao: Measurement in vivo of masticatory mucosal thickness with $20 \mathrm{MHz}$ B-Mode ultrasonic diagnostic Equipment. J. Dent. Res., 68:95-100, 1988.

13）辻本文雄, 多田信平：超音波診断用語事典—一仕組 みと診断のポイント——.ベクトル・コア，東京， 1987, 114.

14) Greenberg, J., Laster, L. and Listgarten, M.A. : Transgingival probing as a potential estimator of alveolar bone level. J. Periodontol., $47: 514-517$, 1976.

15) Roslng, B., Nyman, S. and Lindhe, J.: The effect of systematic plaque control on bone regeneration in infrabony pockets. J. Clin. Periodontol., $3: 38^{-}$ 53, 1976.

16) Lindhe, J., Westfelt, E., Nyman, S., Socransky, S. S., Heijl, L. and Bratthall, G. : Healing following surgical/non-surgical treatment of periodontal disease. J. Clin. Periodontol., 9 : 115-128, 1982.

17) Pihlstrom, B.L., Ortiz-Campos, C. and McHugh, R. B. : A randomized four-year study of periodontal therapy. J. Periodontol., $52: 227-242,1981$.

18) Armitage, G.C., Svanberg, G.K. and Löe, H. : Microscopic evaluation of clinical measurements of connective tissue attachment levels. J. Clin. Periodontol., 4 : 173-190, 1977.

19) Polson, A.M., Caton, J.G., Yeaple, R.N. and Zander, H.A. : Histological determination of probe tip penetration into gingival sulcus of humans using an electronic pressure-sensitive probe. J. Clin. Periodontol., 479-488, 1980.

20) Robinson, P.J. and Vitek, R.M. : The relationship between gingival inflamation and resistance to probe penetration. J. Periodont. Res., $14: 239-243$, 1979.

21) Nyman, S., Lindhe, J. and Karring, T. : Reattachment-new attachment. Text book of Clinical Periodontology, 2ed. J. Lindhe, Munksgaard, Copenhagen, 1989.

22) Listgarten, M.A., Mao, R. and Robinson, P.J. : Periodontal probing and the relationship of the probe tip to periodontal tissues. J. Periodontol., $47: 511-513,1976$.

23) Ingber, J.S, Rose, J.F., and Coslet, G.J. : The "biologic width" a concept in periodontics and restorative dentistry. Alpha Omegan pp. 62-65, Dec. 1977.

24) Gargiulo, A.W., Wentz, F.M. and Orban, B. : Dimensions and relations of the dentogingival junction in humans. J. Periodontol., $32: 261-267$, 1961.

25) Kohler, C.A. and Ramfjord, S.P. : Healing of gingival mucoperiosteal flaps. Oral Surg $13: 89-103$, 1960. 
26) Donnenfeld, O.W., Marks, R.M. and Glickman, I. : The apically repositioned flap-a clinical study. J. Periodontol., $41:$ 381-387, 1964.

27) Tavtigian, R. : The height of the facial radicular alveolar crest following apically positioned flap operations. J. Periodontol., $41: 412-418,1970$.

28) Wood, D.L., Hoag, P.M., Donnenfeld, O.W. and Rosenfeld, L.D. : Alveolar crest reduction following full and partial thickness flaps. J. Periodontol., 43:141-144, 1972.

29）川崎仁：口内法による個体 X線規格撮影とその歯周 疾患治療への応用。口病誌, $34: 164-180,1967$.

30）石原彰恭，松尾良平，大杉光修，芳賀健輔，石川 烈, 木下四郎：歯周外科処置後の経過の臨床的研 究. 日歯周誌, $21: 85-921979$.

31）折笠広樹：歯周処置後の経過観察に関する研究. 日 歯周誌, $22: 216-230,1980$.

32）小林英和：サルの歯槽骨にいろいろな欠損を与えた 場合の修復過程について。 日歯周誌, $38: 404-423$, 1971.

33) Hämmerle, C.H.F., Ingold, H-P. and Lang, N.P. : Evaluation of clinical and radiographic scoring methods before and after initial periodontal therapy. J. Clin. Periodontol., $17: 255-263,1990$.

34) Löst, C., Irion, K.-M. and Nussle, W. : Periodontal ultrasonic diagnosis: experiments on thin bony platelets and on a simulated periodontal ligament space. J. Periodont. Res., 23 : 347-351, 1988.

35) Löst, C., Irion, K.-M. and Nussle, W. : Determination of the facial/oral alveolar crest using RFechograms. An in vitro study on the periodontium of pigs. J. Clin. Periodontol., 16:539-544, 1989.

36) Löst, C., Irion, K.-M. and Nussle, W. : Ultrasonic B-scans of the facial/oral periodontium in pigs. J. Clin. Periodontol., $16: 534-538,1989$.

37）飯島国好：Biologic Width-歯と歯肉と歯槽骨の相 対的関連性，現代の歯科臨床 8，61-74，医歯薬出版， 1985.

38) Dubrez, B., Graf, J.M., Vuagnat, P. and Cimasoni, G. : Increase of interproximal bone density after subgingival instrumentation: a quantitative rediographical study. J. Periodontol., $61:$ 725-731, 1990.

39） Schluger, R.C. : 青野正男（監訳）：シュルーガー最 新歯周治療学, 医歯薬出版, 東京, 1981, 503-504.

\section{連絡先：}

東京医科歯科大学歯学部第二歯科保存学教室

₹ 113 東京都文京区湯島 1-5-45 